\title{
Nutrition Counseling among Patients with Gout
}

\author{
Susyani $^{1}$, Desvianti ${ }^{2}$ \\ ${ }^{1}$ Department of Nutrition, Health Polytechnic Palembang, Indonesia \\ ${ }^{2}$ Muara Dua Hospital, District South OKU Province of South Sumatera, Indonesia
}

\section{Article Info}

Article history:

Received Sep 22, 2017

Revised Nov 27, 2017

Accepted Dec 10, 2017

\section{Keyword:}

Gout

Low-purine diet counseling

Uric Acid

ABSTRACT

Hyperuricemia (high levels of uric acid in the blood) can cause a buildup of monosodium urate crystals. Sudden increase may lead to gout attacks. Consumption of an unbalanced diet, intake of proteins containing high purine is one of the factors that affect gout arthritis. Based on data from medical records at the hospital Mohamad Palembang Hoesin and increase in the number of visits patients with gout, the cumulative incidence of gout reached $22 \%$ after 5 years, the uric acid levels $>9 \mathrm{mg} / \mathrm{dL}$. One of the efforts to help clients change behavior and accelerate the healing process that nutritional counseling is conducted face to face using leaflets media. The purpose of this study was to determine the effectiveness of low-purine diet counseling against uric acid levels in gout patients who were treated at the Hospital dr. AK Gani Palembang. Is a quasi-experimental study design, this study indicated that nutrition counseling with low-purine diet will help to change the behavior of people with gout in the diet to accelerate the reduction in uric acid levels. The average reduction in uric acid levels after being given a lowpurine diet counseling that is equal to $1.6 \mathrm{mg} / \mathrm{dL}$ and concluded that giving low-purine diet counseling are effective in lowering uric acid levels in patients with gout. Based on these results, low-purine diet counseling should be offered to patients with gout in an effort to motivate behavior change and reduction in uric acid levels. Nutrition counseling with Low-purine diet in patients with gout can change the eating habits of patients who eventually decreased the levels of uric acid.
\end{abstract}

Copyright (c) 2017 Institute of Advanced Engineering and Science. All rights reserved.

\section{Corresponding Author:}

Susyani,

Department of Nutrition,

Health Polytechnic Palembang,

Palembang, South Sumatera, Indonesia.

Email: susyani@poltekkespalembang.ac.id

\section{INTRODUCTION}

Nutrition and diet therapy have an important role in the prevention and cure a number of diseases, and are associated with degenerative diseases and metabolism that can not be cured but can be controlled [1]. High uric acid (hyperuricemia) contribute as risk factors for metabolic syndrome in obese [2],[3]. The purpose of the diet in patients with gout is to reduce levels of uric acid in the blood and urine [4],[5].

Nutritional counseling is an effort to speed the healing process and achieve optimal nutritional status. The purpose of nutritional counseling activities are to assist clients in changing behaviors related to nutritional status thus improving nutritional quality and health of the client [4]-[6]. One of the benefits of nutritional counseling is to help speed of the healing process through improved nutrition clients [7]. The new strategy is needed to motivate people with Gout and improve the effectiveness of counseling to begin a better lifestyle and adhere to the diet [8].

In a low-purine diet, the diet should run a lot of carbohydrates and little fat with an adequate amount of water [9]. Many restrictions on food would affect non-compliance to the diet. Noncompliance besides being one of the obstacles to the achievement of the purpose of treatment, will also lead patients require 
examination or treatment is unnecessary. Patients who do not comply will be seen as negligent and that negligence is considered as individuals who have self-control problems [10].

In a study found the incidence of gout: $0.1 \%$ at a level of $<7 \mathrm{mg} / \mathrm{dL}, 0.5 \%$ at levels of 7 to $8.9 \mathrm{mg} /$ $\mathrm{dL}, 4.9 \%$ in blood uric acid levels $>9 \mathrm{mg} / \mathrm{dL}$, the incidence cumulative gout reached $22 \%$ after 5 years, the uric acid levels $>9 \mathrm{mg} / \mathrm{dL}$ [11]. Further research is needed to determine the relationship between nutrition counseling with lifestyle changing in patients with chronic hyperuricemia and gout sufferers [12]. Increased uric acid disorder patients to Palembang, the outline can be seen from the number of patients who went to the department of Dr. Mohammad Hoesin Palembang, based on data from medical records rheumatism clinic, patients with a diagnosis of hyperuricemia in 2008 amounted to 152 people, in 2009 as many as 120 people, while from January to September 2010 as many as 203 patients [13]. This study aims to determine the effectiveness of counseling know the low-purine diet on levels of uric acid in patients with gout outpatient dr. AK Gani Hospital Palembang.

\section{RESEARCH METHOD}

This research used quasi experimental design with a draft form one group pretest-posttest design with the aim to see the difference in uric acid levels in gout patients before and after low-purine diet counseling. Sample size of 30 people who were outpatients at the AK Gani Hospital Palembang. Sampling was done by sysmatic random sampling based on the criteria that have been determined.

For the selection of respondents first screened with uric acid levels, patients with uric acid levels $\geq 7$ $\mathrm{mg} / \mathrm{dl}$ (male) and $\geq 6 \mathrm{mg} / \mathrm{dl}$ (female) will be selected as respondents. Respondents received nutritional counseling by referring to low purine diet leaflets conducted by experienced nutritionists as much as 2 times per week for 4 weeks. Nutritionists provided nutritional counseling in the form of a low purine diet counseling materials include a sense of gout, foods that were allowed and restricted food for consumption and provide motivation for patients adhere to a diet low in purines given.

Intake of nutrients and purine respondents obtained by 24-hour recall method. This study used several equipments which was included : microtoice, bathroom scales, Self Monitoring of Blood Uric Acid, leaf let low-purine diet counseling, identity questionnaire respondents, and form food recall to measure diet adherence respondents. After completion of nutritional counseling using a low purine diet leaflet, then examined uric acid levels to see the effects of nutritional counseling on decreased uric acid levels. To see the effect of nutritional counseling on decreasing uric acid levels in gout patients, the data of the research results were tested statistically by using $t$ dependent test. This research received ethical recommendation from Ethics Committee of Health Polytechnic Makassar Indonesia.

\section{RESULTS AND ANALYSIS}

\subsection{Intake of nutrient and purine}

Respondents in this study were 30 people who comprised $80 \%$ of women and $20 \%$ men. By age group was highest in the age group 50-64 years by $46.7 \%$, the age group $30-49$ years by $30 \%$ and the remaining $23.3 \%$ including the age group $\geq 65$ years.

Based on the results of interviews with use form recall the food was categorized into good if $\geq 80 \%$ of their needs and less if less than $80 \%$ of needs. Purine intake is good categorized if $\leq 150 \mathrm{mg}$ per day and includes not good if $\geq 150 \mathrm{mg}$ per day. The data was then processed by the program Nutrisurvey thus obtained nutrient intake of the respondents is presented in Table 1.

Table 1. Distribution of Respondents Nutrient Intake

\begin{tabular}{llcc}
\hline & Nutrient Intake & $\mathrm{n}$ & $\%$ \\
\hline Energy: & Good & 14 & 46.7 \\
& Less & 16 & 53.3 \\
Protein : & Good & 18 & 60.0 \\
& Less & 12 & 40.0 \\
Fat : & Good & 8 & 26.7 \\
& Less & 22 & 73.3 \\
Carbohydrate: & Good & 7 & 23.3 \\
\multirow{2}{*}{ Purine : } & Less & 23 & 76.7 \\
& Good & 11 & 36.7 \\
& Not Good & 19 & 63.3 \\
\hline
\end{tabular}




\subsection{Dietary adherence}

Dietary compliance of respondents to the low-purine diet counseling was given categorized into two categories, namely obidient and not obidient. Most respondents were 63.3\% non-adherent to low purine diet counseling given and the remaining $36.7 \%$ were considered not obidient, the data can be seen in Table 2 .

Table 2. Distribution of Dietary Adherence of Respondents

\begin{tabular}{lcc}
\hline \multicolumn{1}{c}{ Dietary Adherence } & $\mathrm{n}$ & $\%$ \\
\hline obidient & 11 & 36.7 \\
not- obidient & 19 & 63.3 \\
T o t a l & 30 & 100 \\
\hline
\end{tabular}

\subsection{Effect of low-purine diet counseling to decrease uric acid levels}

To know the effect of giving low purine diet counseling to decrease uric acid levels of respondent was tested statistically using $\mathrm{t}$ - dependent test. Statistical test results show that low purine diet counseling may help reduce uric acid levels of Gout patients. For more details, the data could be seen on Table 3 .

Table 3. Effect of Low-Purine Diet Counseling to Decrease Uric Acid Levels

\begin{tabular}{lccccc}
\hline & $\begin{array}{c}\text { Mean } \\
\text { before } \pm \text { SD }\end{array}$ & $\begin{array}{c}\text { Mean } \\
\text { after } \pm \text { SD }\end{array}$ & T & CI 95\% & p value \\
\hline uric acid levels & $8.42 \pm 2.60$ & $6.82 \pm 1.83$ & 7.10 & $1.13 \pm 2.06$ & 0.000 \\
\hline $\mathrm{P}^{*}: \mathrm{t}$ dependent $\mathrm{p}$ value $<0.005$ & & & &
\end{tabular}

The data in Table 4 showed that giving low-purine diet counseling at the respondent likely reduce uric acid levels, with the average difference uric acid levels before and after low-purine diet counseling by $1.60 \mathrm{mg} / \mathrm{dl}$.

The results of this study showed that Gout is more common in women as much as $80 \%$ and in the age group of 50-64 years is as much as $46.7 \%$. The uric acid levels in men increased by getting older. In women, the increase in Gout patients related to the estrogen hormone. When menopause, estrogen hormone in women decreased dramatically, so the possibility of gout desease increase [14].

As many as $60 \%$ of respondents $\geq 80 \%$ protein intake needs, and respondents still consume protein sources that are high in purines such as, beef, chicken and vegetable protein. To controlling uric acid level in patients with gout, patients should avoid consuming protein sources that are high in purines excessively [9].

Most respondents, $73.3 \%$ of total fat intake more than recommended, and it was caused by that affected often consumed fried foods and foods that were processed by using coconut milk. The patients gout are encouraged to consume fat $\leq 15 \%$ of the total requirement, because fat has a negative impact on uric acid that can inhibit or removal of uric acid excretion via urine. The more fat consumption, the removal of uric acid disorders is increasing [14].

Based on the analysis turned out as much as $63.3 \%$ of respondents intake of purine was high $(\geq 150$ $\mathrm{mg}$. Purine is a compound that is converted into uric acid in the body, hence people with hyperuricemia is not recommended consumption of foods high in purines [15]. The survey results revealed that 19 patients $(63.3 \%)$ did not adhere to the low-purine diet was given, patients still consume foods that contain high purines such as beef, chicken meat and protein sources. Consuming of meat and seafood in high amounts shown to increasing of uric acid levels [16], while the consuming protein or vegetables rich in purine in moderation was not shown to increase the risk of gout patients [17].

Compliance with the health program was a behavior that can be observed and thus can be measured. In a sense obedience was the term used to describe obedience or surrender to the predetermined objectives, while disobedience describe someone's refusal to follow the specified program [18]. In this study, patient compliance was measured by looking at the intake of purines, purine patients who dutifully consume $<150 \mathrm{mg}$, while patients who did not comply consume purines $>150 \mathrm{mg}$. Adherence to a diet program on clients with high uric acid was obedience to not consuming foods that can increase the levels of purine [19].

The average reduction in uric acid levels in the respondents was $2.14 \mathrm{mg} / \mathrm{dL}$ and the statistical test showed a significant decrease and proves that low-purine diet counseling effect to the decreasing of uric acid levels in patients with gout. The result of the research on the effect of a diet low in purines to uric acid levels showed a decrease in uric acid levels result significantly with an average reduction of uric acid levels in respondents was $2.85 \mathrm{mg} / \mathrm{dl}$ [20]. The results of the research on the effects of nutrition counseling with a pocket book using diet in patients with hyperuricemia in the Noongan Hospital North Sulawesi province 
showed a decrease in uric acid levels of patients after receiving nutritional counseling [21]. The main principle of nutrition therapy in patients with gout and hyperuricemia is including restrictions on the amount of purines in the diet and the proper regulation of body weight [6].

The modification of diet in patients with Gout should be noted and highly recommended [22]. Nutritional counseling was very important and absolutely necessary for the long-term well-being in patients with gout [23]. The results of this research was supported by several previous studies that decrease uric acid levels will be significant if given counseling on a diet low in purines, then counseling diet low in purines was important given to patients with Gout to motivate and improve knowledge so that patients change their behaviors and avoiding the consuming foods that contain high in purines that can increase the levels of uric acid.

\section{CONCLUSION}

Unbalanced eating habits, with too high protein and purine intake increase the risk of hyperuricemia. To control uric acid levels, Gout patients need to maintain diet and adhere to diets recommended by nutritionists. Nutritionists need to improve nutritional counseling to Gout patients, because nutrition counseling with Low-purine diet in patients with Gout can change the eating habits of patients who eventually decreased the levels of uric acid.

\section{ACKNOWLEDGEMENTS}

Researchers would like to thank to nutritionist at the Hospital A.K. Gani Palembang and all those who have helped in the implementation of this study.

\section{REFERENCES}

[1] A. Hartono, "Nutrition Therapy and Hospital Dietary," Jakarta, ECG, 2012.

[2] A. Pramono, et al., "Hyperuricemia and its Association with the Presence of Metabolic Syndrome among Indonesian Obese Adolescents," Pakistan Journal of Nutrition, vol/issue: 15(3), pp. 238-243, 2016.

[3] E. P. D. Oliveira, et al., "Dietary, anthropometric, and biochemical determinants of uric acid in free-living adults," Nutrition journal, vol/issue: 12(1), pp. 11, 2013.

[4] S. Almatsier, "Dietary Guide," Jakarta, Gramedia Pustaka Utama, 2008.

[5] Cornelia, et al., "Nutrition Counseling," Jakarta, Penebar Plus, 2013.

[6] Kiedrowski M., et al., "The principles of nutrition therapy of gout and hyperuricemia," vol/issue: 37(218), pp. 115118,2014

[7] I. D. N. Supariasa, "Nutrition Education and Consultancy," Jakarta, Buku Kedokteran EGC, 2013.

[8] A. G. Fam, "Gout, diet, and the insulin resistance syndrome," The Journal of Rheumatology, vol/issue: 29(7), pp. 1350-1355, 2002.

[9] I. Junaidi, "Rheumatism and Uric Acid (Revised Edition)," Jakarta, Bhuana Ilmu Populer, 2012.

[10] N. D. Pratita, "The Relation of Spouse Support and Health Locus of Control for Obedience of Recovering Process of Diabetes Mellitus Type 2," Scientific Journal Student of Surabaya Univercity, vol/issue: 1(1), 2012.

[11] R. Hidayat, 2012. Available: http://www.pikhospital.co.id/news/2012/10/08/17/desease-rheumatism-uricacid-gout.

[12] J. V. Mellado and E. A. Hernández, "Primary prevention in rheumatology: the importance of hyperuricemia," Best Practice \& Research Clinical Rheumatology, vol/issue: 18(2), pp. 111-124, 2004.

[13] Nuryani, "The Impact of Diet Issue (Energy, Protein, Fat, Carbohydrate and Purine) Toward Final Uric Acid Levels of Hyperuricemia at Polyclinic Mohamad Hoesin Hospital Palembang," (Scientific Paper) Departement of Nutrition Health Polytechnic Palembang Indonesian, 2011.

[14] T. Sutanto, "Detection, Prevention, Medical Treatment of Uric Acid," Yogyakarta, Buku Pintar, 2013.

[15] Y. Harlinawati and A. Khomsan, "Juice Therapy for Rheumatism and Uric Acid," Depok, Puspa Swara, 2008.

[16] H. K. Choi, et al., "Intake of purine-rich foods, protein, and dairy products and relationship to serum levels of uric acid: the Third National Health and Nutrition Examination Survey," Arthritis \& Rheumatology, vol/issue: 52(1), pp. 283-289, 2005.

[17] H. K. Choi, et al., "Purine-rich foods, dairy and protein intake, and the risk of gout in men," $N$ Engl $J$ Med, vol/issue: 2004(350), pp. 1093-1103, 2004.

[18] S. B. Bastable, "Nurse as Educator: Principle of Teaching and Learning," Jakarta, EGC, 2002.

[19] R. A. Pangesti, "Factors that Influence Obedeance of Dietary topatient of Uric Acid at Public Health Centre Mandiraja 1, Distric Banjarnegara Province of Central Java," Muhammadiyah Univercity Purwokerto, Indonesian, 2013.

[20] F. Bediawati, "The Impact of Low Purine Diet towards Uric Acid Levels of Gout/Hyperuricemia Outpatient Patients at Nutrtition Polyclinic Mohamad Hoesin Hospital Palembang," Departement of Nutrition Health Polytechnic Palembang Indonesian, 2004. 
[21] M. R. Reppie, et al., "The Impact of Nutrition Counseling with Dietary Pocket Book to Hyperuricemia Outpatient Patient at Noongan Hospital, Province of North Sulawesi," The Indonesian Journal of Clinical Nutrition, vol/issue: 4(1), pp. 35-42, 2016.

[22] R. L. Wortmann, "Gout and hyperuricemia," Current Opinion in Rheumatology, vol/issue: 14(3), pp. 281-286, 2002.

[23] R. N. Beyl Jr, et al., "Update on Importance of Diet in Gout," The American Journal of Medicine, 2016. 